\title{
成人高位股関節脱臼に対する THA
}

$\begin{array}{rrrr}\text { 熊本大学整形外科 } & & & \\ \text { 前 田 } & \text { 智・井 手 淳 二 } \\ \text { 山 鹿 眞紀夫. 高 木 } & \text { 克 }\end{array}$

\section{Total Hip Arthroplasty for High Positioned Dislocated Hips in Adults}

\author{
Satoshi Maeda, Junji Ide, Makio Yamaga, \\ and Katsumasa Takagi
}

Department of Orthopaedic Surgery,

Kumamoto University School of Medicine, Kumamoto, Japan

Total hip arthroplasty (THA) for high positioned dislocated hips was performed on six cases. All patients were women. The mean patient age was 55.0 years (range; 37 to 68 ).

Attempts were made to correct the leg-length discrepancy to an appropriate length in each case. The greatest lengthening was $45 \mathrm{~mm}$ (12.5\% femoral lengthening) in the series reported. There were no major complications with severe nerve palsy due to overlengthening of the femur, but a patient with $40 \mathrm{~mm}(10.4 \%)$ femoral lengthening complained of numbness in the lateral sural cutaneous nerve area.

We consider that the appropriate leg-lengthening should be within $10 \%$ of femoral lengthening.

Key words : High positioned dislocated hip (高位股関節脱臼), adult (成人), total hip arthroplasty（人工股関節全置換術）, leg-lengthening（脚延長）, complication (合併症)

\section{はじめに}

高位脱臼性股関節症の治療法として, 当科では人工 股関節置換術（以下 THA）を試みている。この際, 特に片側例ではかなりの脚長差を認めることが多いた め, 脚延長を行う必要があるが, その弊害として神経 の牽引による障害が問題となる ${ }^{1-315166}$. しかしながら， 安全な脚延長量に関する明確な基準は今のところない.

今回, 高位脱臼性股関節症に THA を施行した症例 で, 脚延長と神経障害との関連について検討したので 報告する。

\section{対象と方 法}

木下らの分類" に従い, 骨頭が明らかに腸骨壁との
間に新臼蓋を形成しているI型，および骨頭が殿筋内 に遊離している开型を対象とした。

当科で治療した 5 例 6 股は, 全例女性であり, 平均 年齢は 55.0 歳（37 歳〜 68 歳）であった。而型の 4 股 中 2 股は Schanz 手術を施行されており，1 股は腸骨 翼に対して骨頭による圧痕を形成していた，臼蓋カッ プの設置は原臼位 4 股，高位 2 股であった。

術前・術後の単純レ線から, 下肢延長量の大腿骨長 に対する延長率（\%）を算出し, 術後の臨床的神経症 状の有無との関連について調査した。手術は全例 transtrochanteric approachにて進入，臼蓋上方 への骨頭骨移植を施行し，一期的引き下げによる脚延 長を行った. 
結

果

脚延長量は, $11 \sim 45 \mathrm{~mm}$, 各々の大腿骨長に対する 脚延長率は最小 $2.9 \%$, 最大 $12.5 \%$ であった（表 1 ). 延長率 $10.4 \%$ の症例(4)で軽度の知覚障害がみられた が, 他の症例で明らかな神経障害を認めたものはなかっ た。尚，両側高位脱臼例で，対側を高位に固定術が施 行されていた 1 例については，高位に妇蓋を設置し， 脚延長を行わなかったので除外した。

代表症例を呈示する.

症例(3)；67 歳, 女性（図 1)
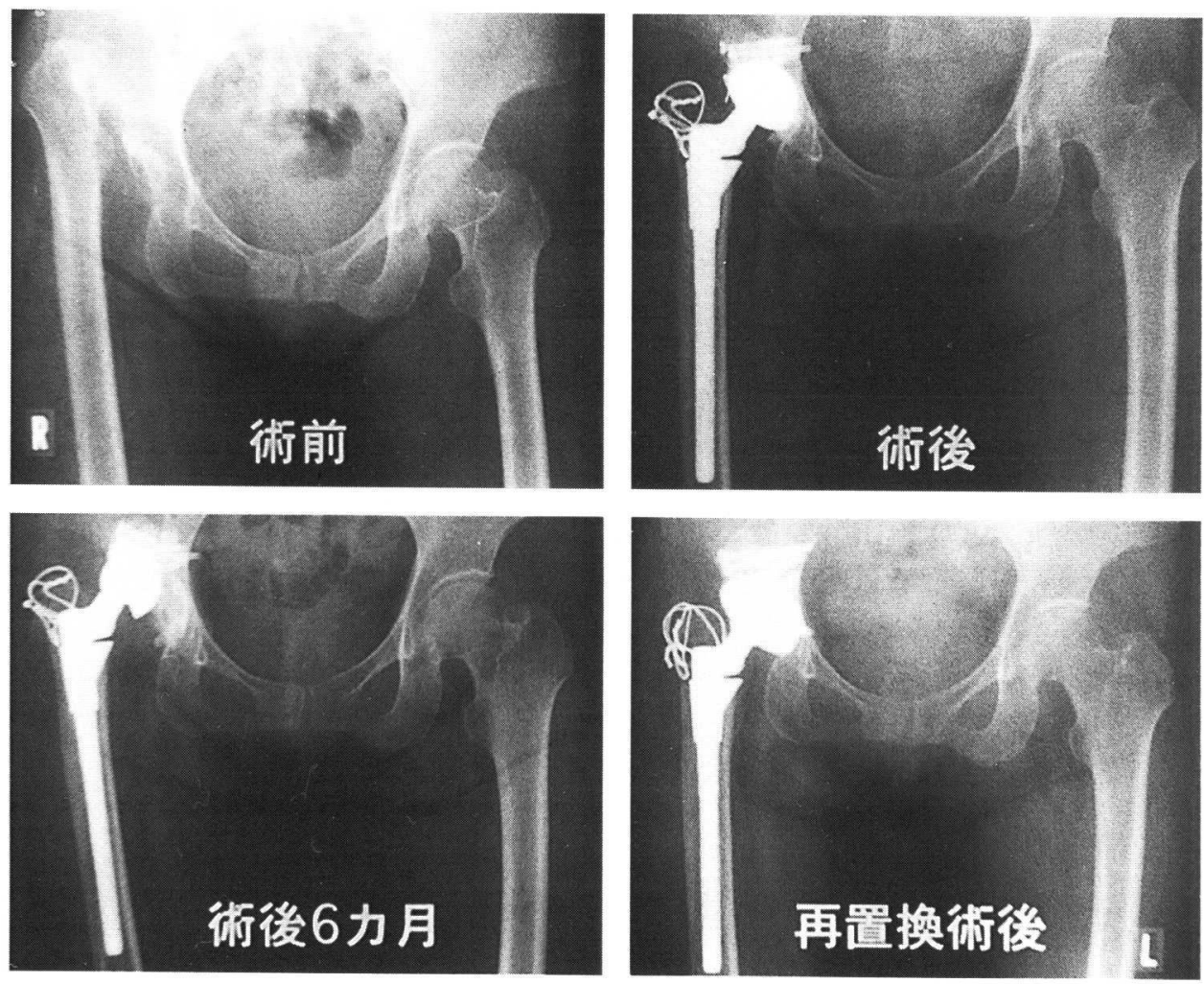

図 1 症例(3), (4)

a (上段左) ; 術前単純レ線像。而型の殿筋内脱臼股，腸骨翼に骨頭による圧痕を 生じていた

b（上段右）； THA 施行。一期的な下肢の引き下げによる脚延長は $37 \mathrm{~mm}$ ，その大 腿骨長に対する延長率は $9.1 \%$ であった。術後，下肢の筋力低下，知 覚障害は特に認めなかった。

c (下段左); 術後6 ケ月, 転倒のため臼蓋カップの脱転と螺子の折損を生じた.

$\mathrm{d}$ (下段右) ; 再置換術施行。下枝引き下げは $40 \mathrm{~mm}$, 脚延長率は $10.4 \%$ であった。 術後, 運動障害は認めないものの, 下腿外側から足背外側にかけて のしびれ感を生じた. 
表 1 各症例の脚延長と神経障害との関係について

\begin{tabular}{c|c|c|c|c|c|c}
\hline \hline 症 例 & 脱臼度分類 & 対側股 & 四蓋設置 & 脚延長量 & 脚延長率 & 神経障害 \\
\hline (1) 37 歳女 & II 型 & 正常股 & 原臼位 & $11 \mathrm{~mm}$ & $2.9 \%$ & - \\
\hline (2) 50 歳女 & II 型 & 変股症 & 高位 & $22 \mathrm{~mm}$ & $5.5 \%$ & - \\
\hline (3) 67 歳女 & II 型 & 正常股 & 原臼位 & $37 \mathrm{~mm}$ & $9.1 \%$ & - \\
\hline (4) 68 歳女 & III 型 & 正常股 & 原臼位 & $40 \mathrm{~mm}$ & $10.4 \%$ & + \\
\hline (5) 53 歳女 & III 型 & I -B 型 & 原臼位 & $45 \mathrm{~mm}$ & $12.5 \%$ & - \\
\hline
\end{tabular}

$37 \mathrm{~mm}$ ，その大腿骨長に対する延長率は $9.1 \%$ であっ た。術後, 下肢の筋力低下, 知覚障害等は特に認めな かった。

症例(4)は症例(3)と同一症例であるが, 術後 6 ケ月の 時点で, 転倒により臼蓋カップの脱転と螺子の折損を 生じたため, 再置換術を施行した。その際の下肢引き 下げは $40 \mathrm{~mm}$ ，脚延長率は $10.4 \%$ であった。術後， 運動障害は認めないものの, 下腿外側から足背外側に かけてのしびれ感を生じた。

\section{考察}

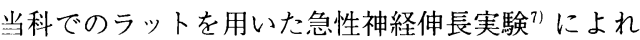
ば，大腿骨長の $20 \%$ 脚延長群では，坐骨神経におけ る逆行性軸索流, 神経内血流, および組織学的変化の 面で障害が出現するものの，10\% 延長群では有意な 変化を認めなかった。そこで THA の際に脚延長が必 要な場合, 我々は大腿骨長の $10 \%$ 延長を指標として 行っている.

自験例での脚延長率は最大 $12.5 \%$ であったが， $10.4 \%$ 延長した 1 例にのみ軽度知覚障害を認めた。 脚延長率は $10 \%$ 以内にとどめるのが妥当であると思 われる。

$$
\text { ま と め }
$$

(1)高位脱臼性股関節症に対する THA 施行例におい
て，大腿骨長に対する脚延長率と神経障害との関連に ついて調査した。

(2)大腿骨長に対する脚延長率は，最大で $12.5 \%$ で あり，1 例（脚延長率 $10.4 \%$ ）に軽度の神経障害を認 めた。

現段階では脚延長率は $10 \%$ 程度を目安としている。 今後症例を重ね，更に検討していきたい。

\section{参 考 文 献}

1) Dunn, H.K. et al.: Total hip reconstruction in chronically dislocated hips. J. Bone Joint Surg., 58A : 838-845, 1976.

2）長谷川功ら：脱臼位股関節症に対する人工関節手術. 整形外科, $40: 5-14,1989$.

3）広畑和志, 梁 復興, 武部恭一：股関節手術にみられ る大腿神経麻瘦について。臨整外，13：910-917, 1978.

4) 木下 勇, 武田芳嗣, 西岡 隆: 成人脱臼股への人工 股関節置換術の適応と方法. Journal of Joint Surgery, $15: 73-82,1996$.

5）沢本 毅ら：高位股関節脱臼に対する人工股関節置換 術の成績. Hip Joint, $20: 247-249,1994$.

6）武部恭一ら：高位脱臼性股関節症に対する手術に合併 した坐骨神経麻瘢について。整形外科，30：913-917, 1979.

7) Tanoue, M. et al.: Acute Stretching of Peripheral Nerves Inhibits Retrograde Axonal Transport. Journal of Hand Surgery, 21-B : 358-363, 1996. 